\title{
Development of TVET Teachers' Beliefs about Technology Enriched Instruction through Professional Development Workshops: Application of the Technology Acceptance Model
}

\author{
Sallimah M. Salleh ${ }^{1}$, Juraidah Musa ${ }^{2}$, Jainatul Halida Jaidin ${ }^{3}$, Masitah \\ Shahrill ${ }^{*}$ \\ ${ }^{1}$ Sultan Hassanal Bolkiah Institute of Education, \\ Universiti Brunei Darussalam, Jalan Tungku Link, Gadong, Bandar Seri Begawan, BE1410, BRUNEI \\ DARUSSALAM
}

*Corresponding Author

DOI: https://doi.org/10.30880/jtet.2021.13.02.003

Received $3^{\text {st }}$ July 2020; Accepted $10^{\text {th }}$ August 2020; Available online $30^{\text {th }}$ June 2021

\begin{abstract}
This study explores how Technical and Vocational Teachers' intentions to incorporate technology in teaching and learning are influenced by their beliefs. It is theorised that teachers' beliefs about using technology in their instructions are influenced by teachers' perceptions of technology usefulness, ease of use, and self-efficacy. In the current study, a series of workshops for technology-enriched instructions were mounted for the professional development of technical and vocational teachers. In these workshops, teachers planned, designed and developed $21^{\text {st }}$ century learning activities. Data was collected using a questionnaire, which was distributed to the TVET teacher participants after the completion of the professional development workshops for technology-enriched instruction. The data was subjected to confirmatory factor analysis, and structural equation modelling which were used to analyze the proposed modified Technology Acceptance Model (TAM) model. The modified TAM model proposed that TVET teachers' intention to use technology, and their beliefs about self-efficacy are directly influenced by their beliefs about perceived ease of use, and perceived usefulness of technology, and that the variable, self-efficacy is a mediator variable to intention. It was shown that the proposed modified TAM model is a good fit model to explain the variance in $52 \%$ of teachers' beliefs about the self-efficacy, and $40 \%$ variance of intention. The positive outcome of the technology enriched instruction professional development program is that it provided a common language and skills that overcame some of the TVET teachers' concerns with regards to technology integration in their lessons. This study contributes towards an understanding of the factors that influence TVET teachers' intentions to use technology in teaching and learning through a professional development programme for technology enriched instruction.
\end{abstract}

Keywords: Perceived behavioral control, teacher attitudes, teacher beliefs, technology acceptance model, 21st century skills

\section{Introduction}

The call for technology integration in teaching and learning has been made official in the Brunei National System of Education for the 21st century. Although the literatures show evidences of the use of Information and Communication Technology (ICT) in teaching and learning is increasing (Livingstone, 2012), the case of Brunei achieving 'technology integration' is pacing slowly. Nonetheless, as we strive to use more technology, we need to identify teachers' beliefs about their decisions to integrate technology in the classroom (Deng, Chai, Tsai, \& Lee, 2014; Ebil, Salleh \& Shahrill, 2020). This study provides insights into factors influencing teachers' beliefs in relation to the use of technology in their

*Corresponding author: masitah.shahrill@ubd.edu.bn

25 
instructions and the prevalent practices of teaching and learning in technical and vocational classrooms. Efforts to promote the development of 21 st century skills among students are not new in the context of Technical and Vocational Education and Training (TVET).

In Brunei Darussalam, as in many other countries, various professional development programs for TVET teachers have been implemented to equip teachers with relevant pedagogical skills for 21 st century learning designs. However, very few researchers have taken the challenge to investigate the extent to which these programs have been successful in influencing TVET teachers' beliefs about incorporating dimensions of the 21 st century in their teaching and learning practices. Understanding these factors may offer insights into why many professional development workshops are ineffective in getting teachers to use newly acquired skills in their daily practices (Cox, 2010).

The current study investigates the factors that influence the TVET teachers' intentions to integrate technology in their teaching. In particular, this study explored how TVET teachers' beliefs influence their intention to use technology as an outcome of a technology-enriched instruction professional development program (Slykhuis \& Lee, 2016). TVET can be viewed as an education system that incorporates the acquisition of knowledge and equipping learners with practical skills and work-based experience for occupational fields (Ehlers, Schuwer, \& Janssen, 2018). Previous studies have found that teachers in TVET need to be given basic training in computer use, and how best to integrate ICT to effectively achieve students' learning outcomes (Ramadan, Chen, \& Hudson, 2018; Yasak \& Alias, 2015). Nevertheless, there is paucity in studies that examine how TVET teachers' beliefs may be influenced through professional development for technology integration in the TVET curriculum. With the surging demand for ICT and the need for higher knowledgebased workers, TVET teachers would have to re-evaluate their teaching by incorporating technology and 21 st century skills into their curriculum.

There has been a great interest specifically in teachers' beliefs about 21 st century teaching and learning, and their beliefs towards technology integration. Teachers' beliefs were found to be related to their technology integration practices (Kim, Kim, Lee, Spector, \& DeMeester, 2013; Vongkulluksn, Xie, \& Bowman, 2018) and such pedagogical beliefs play an important role in a teacher's decision-making especially when it comes to planning and designing lesson activities (Boschman, McKenney, \& Voogt, 2014). Thus, it can be argued that teacher beliefs have a strong impact on how they teach and incorporate technology for the attainment of 21 st century skills in a classroom. These beliefs are usually developed through a professional development program that focuses on addressing teachers' sustained skills, personal perceptions, and interest.

As we are living in an ever-changing world, there is a growing need to instil 21 st century skills among students. There have been discussions about how schools are not effectively preparing students with 21st century skills through technology integration. Moreover, it appears that basic skills would not be sufficient for students to compete in the current socio-economy. They would have to be capable of solving problems, think critically, be creative, innovative and be able to interact competently with other citizens (Kay \& Greenhill, 2011). Today, teachers of primary, secondary and TVET are required to design and develop activities that would promote 21 st century skills which in turn, would produce students to be active problem-solvers, team player and digitally literate citizens (Kale \& Goh, 2014). In addition, they would need proper training or professional development on how to incorporate 21st century skills into their lessons more meaningfully (Lambert \& Gong, 2010; Wood et al., 2017). Duran, Yaussy, \& Yaussy (2011) showed positive results from student engagement through collaboration and the use of 21 st century skills. Erstad, Eickelmann, \& Eichborn (2015) proposed teachers as "agents of change" and in their research, their objective was to reflect on the impact and challenges of those ways. They also recommended that educators would need to create more accessible contemporary frameworks and research on 21 st century competencies for teachers. Defining and the implementation of 21 st century competencies and skills through technology integration are strategies that most schools are putting great importance on specifically, digital competence, information literacy, or ICT literacy.

Due to this, there has been a lot of research, particularly case studies, on innovative pedagogical practices using ICT (Voogt, Fisser, Pareja Roblin, Tondeur, \& van Braak, 2013). Tondeur and colleagues (2017) reviewed 14 qualitative research studies to understand the relationships between teachers' pedagogical beliefs and their educational uses of technology. It was found that there is evidence how this relationship can facilitate the integration of technology in education. Hence, it seems that when it comes to integrating 21 st century skills in classrooms, majority of the research focused combining several 21 st century skills with the use of ICT. The following paragraphs looks at teachers' beliefs about technology in instruction.

One of the 21 st century skills that are essential to learners would be digital literacy. Learners need to be able to use digital technology aptly in order to evaluate and create information in this technology-driven world. As there is a demand for integration of ICT in the school curriculum, teachers view this as a challenge to input technology into their lessons (Albion, Tondeur, Forkosh-Baruch, \& Peeraer, 2015; Ebil, Salleh \& Shahrill, 2020). With ample school support, easy access to technology resources and, teachers' beliefs about technology, these could influence teachers' attitudes towards using technology in their lessons (Voogt \& McKenney, 2017). Further evidence show that teachers are likely to use technology meaningfully if it matches their pedagogy (Inan, Lowther, Ross, \& Strahl, 2010). In addition, Chien, Wu, \& Hsu, (2014) indicated that teachers who usually use technology in their lesson tend to have a more positive outlook towards using it. Though this may be true, the finding may not apply to all teachers because using technology might not be as readily assimilated into teachers' usual teaching (Tondeur et al., 2017). In addition, if teachers possess negative 
attitudes toward using emerging technologies, lack understanding on how to use them meaningfully, or are constrained by the limited student or teacher technology access, it is unlikely they will engage these tools in their lessons (Kale $\&$ Goh, 2014). Hsu (2016) examined the beliefs, practices and barriers towards technology integration on 152 teachers and discovered that a majority of them possess constructivist pedagogical beliefs because they held high self-efficacy beliefs about technology use. In contrary to this, lack of time to implement technology-integrated lessons, lack of training in the use of technology and lack of technical support were some of the teacher barriers in the use of ICT. In general, there are studies that were research on teachers integrating 21 st century skills and using ICT in their classroom, as well as professional development for teachers. However, there has not been a lot of focus towards TVET teachers particularly their beliefs and intentions to the use of technology in TVET teaching and learning.

\subsection{Research Problem and Objectives}

Teachers often find time as a constraint for designing lessons that specifically address the incorporation of technology and 21 st century skills, as the teachers' work may be overwhelming. This study introduced a technology-enriched instruction professional development program to provide a platform for teachers to learn and work together in the design of 21 st century lessons that integrate technology. In this way, a technology-enriched instruction professional development program was aimed at addressing the personal, social and perceived control of the teachers' needs so that the program can change teachers' beliefs positively. The overall design of the technology-enriched instruction professional development program included: (1) collaboration among teachers (social factors), and (2) promoting teachers' understanding of the benefits of technology-enriched instruction (personal factor). In addition, the technologyenriched instruction professional development framework, which is a tool for designing and planning lesson activities that develop 21 st century skills as well as develop students' higher-order thinking skills and creativity, was used in the professional development program.

The overarching research objective that framed the course of this study is to investigate the factors influencing TVET teachers' use of technology for the development of 21 st century skills in TVET students through a technology enriched instruction professional development program. To achieve this objective the following research question is formulated: (1) How do the direct factors of perceived ease of use, perceived usefulness, influencer variables students, teachers and others relate to teachers' intention? (2) How do the direct factors of perceived ease of use, perceived usefulness, influencers (students, teachers, and others) relate to teachers' belief on self-efficacy? and (3) How does the direct factors explain teachers' intention to use technology in teaching and learning?

\subsection{Theoretical Framework, Hypotheses and Research Questions}

The theoretical framework underpinning the current study is the Technology Acceptance Model (TAM) (Davis, 1989), which posits that beliefs about ease of use, and perceived usefulness of technology influence attitudes towards using technology, which in turn influence intention to use, and actual behaviour. Lai \& Bower (2019) reported a systematic review of literature of the evaluation of technology usage in education, and has shown that about $62 \%$ of the reviewed journal articles focused on affective elements such as perceptions, intentions or preferences, attitudes, values, beliefs and self-efficacy. Following the tradition of the vast majority of the research on technology use in education, the current study attempts to model the TAM and investigates the direct relationships of the constructs of the TAM model (perceived usefulness, and perceived ease of use), and influencers (teachers, students and other people) on teachers' selfefficacy beliefs, and intention to use technology in teaching and learning. Figure 1 shows the original constructs of the TAM model, viz. perceived usefulness, and perceived ease of use are directly related to behavioural intentions to use, and indirectly related to actual system use. In the modified TAM model, we attempt to investigate how the variable, selfefficacy, fits into the TAM model. In the modified TAM model, the variable, self-efficacy is a placed as mediator variable. It is hypothesised that the variables, perceived usefulness, and perceived ease of use influence teacher self-efficacy, which motivate their intention and use of technology in teaching and learning.

This current study proposed a modified TAM model, and investigates the research hypotheses that perceived usefulness, and perceived ease of use have positive direct effect on intention and self-efficacy; as that self-efficacy is a mediator variable. For the purposes of analyses, the modified TAM model was tested statistically using confirmatory factor analysis and structural equation modelling to provide answers to the following research questions: (1) How do the direct factors of perceived ease of use, perceived usefulness, influencer variables students, teachers and others relate to teachers' intention?, (2) How do the direct factors of perceived ease of use, perceived usefulness, influencers (students, teachers, and others) relate to teachers' belief on self-efficacy?; and (3) How does the direct factor explain teachers' intention to use technology in teaching and learning? 


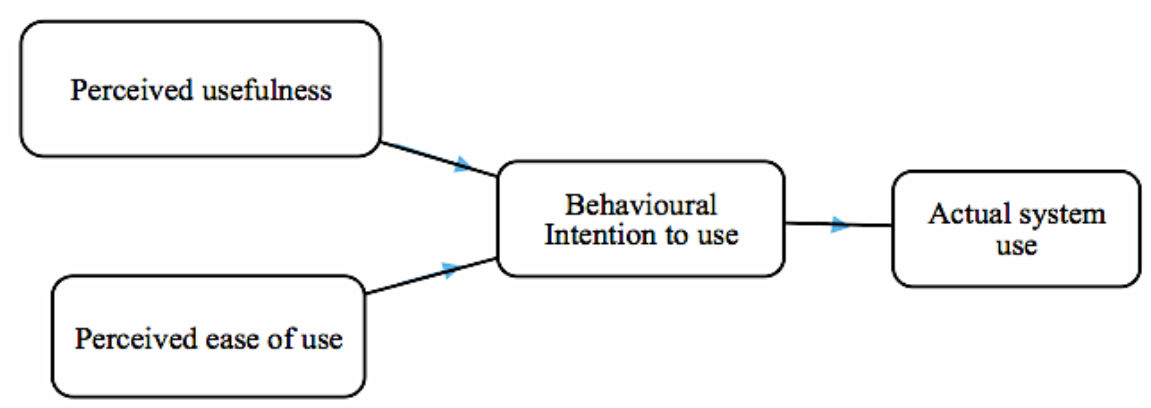

Fig. 1 - The Original Technology Acceptance Model (Davis, 1989)

\section{Methodology}

This research is a quantitative study that employed a questionnaire for data collection. The questionnaire was administered to a group of TVET teachers who attended the TEI professional development workshops. A total of 115 TVET teachers were involved in the study. The TVET teachers were selected by their respective schools to attend the professional development workshops. The teachers underwent a two-day workshop in designing technology-enriched instructions. At the end of the two-day workshop, they were requested to respond to the questionnaire. Table 1 shows the number of teachers that participated in the workshops from the respective TVET institutions in Brunei Darussalam.

Table 1 - Percentage of participants for professional development workshops

\begin{tabular}{ccc}
\hline Institution code & Frequency & Cumulative percent \\
\hline TVET1 & 14 & 12.2 \\
TVET2 & 3 & 14.8 \\
TVET3 & 24 & 35.7 \\
TVET4 & 15 & 48.7 \\
TVET5 & 21 & 67.0 \\
TVET6 & 17 & 81.7 \\
TVET7 & 21 & 100 \\
\hline Total & 115 & 100 \\
\hline
\end{tabular}

The participants consisted of $43 \%$ TVET teachers who have between 1 to 5 years teaching experience; $44 \%$ were TVET teachers who taught between 6 to 20 years, and rest were teachers (13\%) who have more than 21 years teaching experience.

\subsection{Instrument}

The questionnaire comprised a total of 35 items, derived and modified from the constructs of the Technology Acceptance Model. The questionnaire was distributed via online to all participants of the workshop using convenient sampling. A total of 115 teachers completed the questionnaire and the return rate was $100 \%$. The questionnaire was adapted and modified from a previous similar study on eliciting factors influencing secondary teachers' use of ICT in teaching comprising of teachers' attitudes, subjective norms and perceived behavioural control (Salleh, 2016, Salleh \& Laxman, 2014). Cronbach's Alpha reliability of the questionnaire is .914.

\section{Results and Discussions}

Statistical analyses involved confirmatory factor analysis and structural equation modelling. The factor loadings generated from the confirmatory factor analysis for the total sample is presented in Table 2, where all the items reached above the threshold value of .4 were identified and matched for a particular construct. Using SPSS software, the fivefactor extraction was requested for the CFA model for the five latent variables, Perceived Ease of Use (peou2), perceived usefulness (pu2), influencers (student, teachers, others), self-efficacy (selfeff), and Intention (intend2).

Table 2 shows the factor loadings of each of the items of the questionnaire for each factors: Factor 1 (Perceived usefulness) comprising of items numbers 8,13,17,18, 23,25,27,28,32,33, and 35); Factor 2 (teacher, students and others as influencers) comprising of items numbers 9,10,11,19,20,29,30 and 31; Factor 3 (Perceived Ease of Use) comprising of item numbers 6,7,16, and 26; Factor 4 (Self-efficacy) comprising of item numbers 12,14,24 and 34; and Factor 5 (Intention) comprising of item numbers 15, 21, and 22. For items that loads on two factors, decision on choosing the best construct was made by either taking the higher factor loading or by making arbitrary reference to the constructs of TAM. For instance, for items 7, 9, 10 16, 24, and 34, it was decided to choose the factor (or construct) that shows the higher 
factor loadings. For instance, item 7 loads on Factor 1 (perceived usefulness) and Factor 3 (Perceived Ease of Use) with factor loading of .519 and .548 respectively. It was decided to load item 1 on the Factor 3, which shows the higher factor loading. As for the other items $(11,12$, and 15), it was decided to arbitrarily select the lower factor loading since the item statements match the chosen factor or construct. For example, item 11 falls on Factor 1 (perceived usefulness) and Factor 2 teachers (as influencers) with factor loadings of .684 and .421 respectively. However, item 11 fits the description of the construct (Factor 2) of other (other people as influencers). Note that items numbers 1 to 5 were not included in Table 2 as they are demographic items.

Table 2 - Confirmatory factor loadings of items on the five-factor model

\begin{tabular}{|c|c|c|c|c|c|}
\hline \multirow[b]{2}{*}{ No. } & \multicolumn{5}{|c|}{ Factors } \\
\hline & 1 & 2 & 3 & 4 & 5 \\
\hline 6 - I believe that technology for teaching and learning would be easy to use & .385 & .038 & .711 & .258 & -.106 \\
\hline 7 - I believe that using technology in teaching would improve my delivery of the course. & .519 & .210 & .548 & .262 & .020 \\
\hline 8 - I would like to use technology in teaching and learning for delivery of my course & .711 & .181 & .348 & .085 & .115 \\
\hline 9 - I think other teachers in my school/college would be in favour for using technology. & .411 & .490 & .394 & -.217 & .151 \\
\hline 10- I think students would be in favour of utilizing technology & .400 & .595 & .303 & .142 & -.067 \\
\hline 11- Most people who are important to me think that it would be fine for me to use tech & .684 & .421 & .120 & .149 & .161 \\
\hline 12- I am confident about using technology in teaching and learning & .628 & .128 & .228 & .440 & .076 \\
\hline 13- I would be able to actively use technology in teaching and learning & .617 & .168 & .369 & .274 & .174 \\
\hline 14- I have a sufficient extent of knowledge to use technology & .123 & .135 & .312 & .754 & .047 \\
\hline 15- I predict I would use technology in the teaching and learning & .536 & -.033 & .316 & .241 & .464 \\
\hline 16- I believe it would be easy to access course materials using technology & .417 & -.045 & .469 & .104 & .418 \\
\hline 17-I believe that technology would allow my teaching and student learning more efficient. & .607 & .251 & .370 & .223 & .249 \\
\hline 18-Using technology in teaching and learning of my course would be pleasant experience. & 660 & .197 & .277 & .160 & .142 \\
\hline 19- I think other teachers in my school/college would believe using technology is useful. & .360 & .477 & .315 & .043 & .292 \\
\hline 20- I think students would believe that technology in teaching is useful & .538 & .463 & .352 & .195 & .267 \\
\hline 21- I think other teachers in my school/college would be willing to use & .259 & .363 & .202 & -.068 & .662 \\
\hline 22- Using technology in teaching and learning for my courses would challenge me & .075 & .164 & -.135 & .042 & .833 \\
\hline 23- I would have more opportunities to create knowledge in my course & .668 & .161 & .249 & .232 & .287 \\
\hline 24- I have a sufficient extent of self-confidence to make a decision to utilize technology & .407 & .063 & .091 & .797 & .066 \\
\hline 25- I plan to use technology in the teaching and learning of my courses & .820 & .120 & .145 & .114 & .185 \\
\hline 26- I believe that technology in teaching and learning would be easy to implement & .110 & .330 & .672 & .339 & .080 \\
\hline 27- I believe that using technology would be useful for teaching and learning & .771 & .361 & .230 & .123 & .142 \\
\hline 28- Using technology in teaching and learning of my courses is a wise idea & .744 & .312 & .276 & .135 & .158 \\
\hline 29- I think other teachers in my school/college would possess adequate skills & .072 & .690 & .175 & .271 & .20 \\
\hline 30- I think students would possess adequate skills in using technology & .376 & .799 & -.113 & .099 & .159 \\
\hline 31- Most people who are important to me would be in favour in my use of technology & .621 & .469 & -.044 & .175 & .157 \\
\hline 32- I would be comfortable to use technology in teaching and learning & .779 & .235 & .173 & .255 & .055 \\
\hline 33- I would be able to control the pace of learning in my class & .650 & .223 & .036 & .336 & .116 \\
\hline 34- I have a sufficient extent of self-confidence to make decisions to use technology & .465 & .206 & .163 & .731 & -.028 \\
\hline 35- I intend to use technology in the teaching and learning of my courses & .746 & .248 & .154 & .270 & -.037 \\
\hline
\end{tabular}

Extraction Method: Principal Component Analysis.

Rotation Method: Varimax with Kaiser Normalization.

Based on the results of the confirmatory factor analyses, an assessment of the overall structural model using Structural Equation Modelling (SEM) was conducted using AMOS Version 26 software. Figure 2 shows the modified TAM Model 2 (after adjustment). The following research hypotheses were tested using SEM, and the results of hypotheses tests are drawn out to assess the research hypotheses, and ultimately answer the research question.

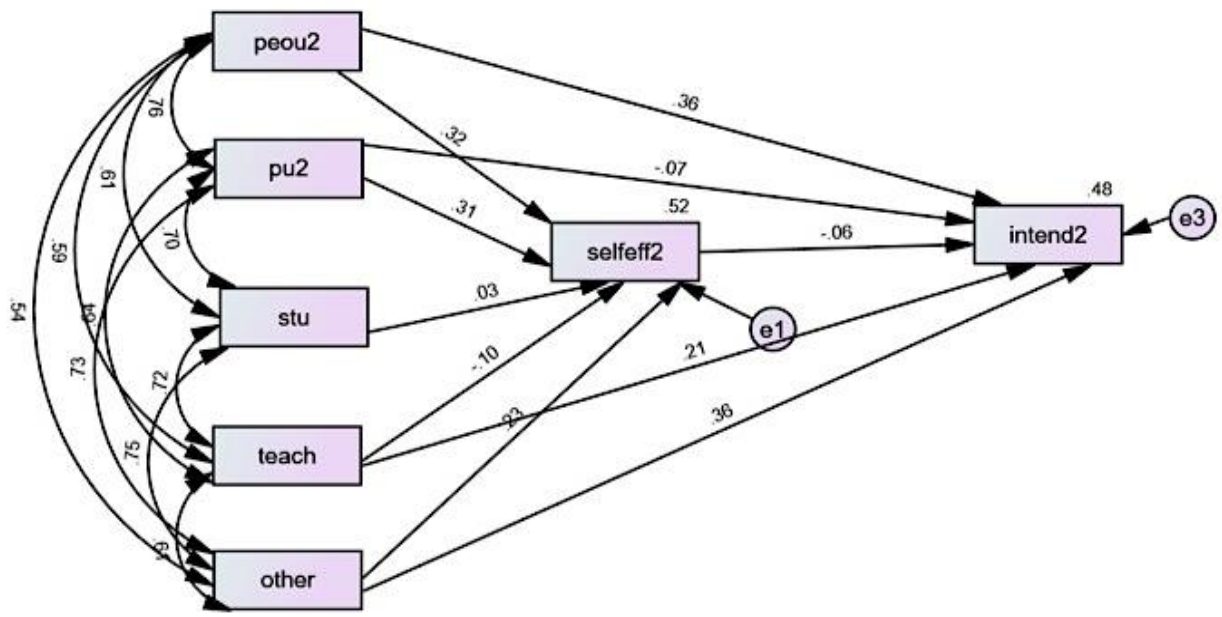

Fig. 2 - Modified TAM Model 2 (after adjustment) 
The first research question was: How do the direct factors of perceived ease of use, (peou2); perceived usefulness (рu2); students, teacher, and others (as influencers) relate to teachers' intention (intend2)? The following Table 3 shows the statistically significant path coefficients from peou2 to intend $2(B=.36 ; p=.002)$; teach $(B=.21 ; p=.038)$; and other $(B=.36 ; \mathrm{p}=.001)$ at $\mathrm{p}<.05$. Therefore, the following hypotheses formulated to answer the research question were accepted: Hypothesis H1 : There is positive relationship between teachers' belief about perceived ease of use and intention.

Hypothesis H3 : There is positive relationship between teachers' beliefs about teachers as influencers and intention. Hypothesis H4 : There is positive relationship between teachers' beliefs about others as influencers and intention. Hypothesis H2 : (There is positive relationship between teachers' beliefs about self-efficacy and intention) is rejected as the path coefficient from selfeff 2 to intend $2(B=-.059 ; \mathrm{p}=.564)$ is not significant at $\mathrm{p}<.05$.

Table 3 - Path Coefficients (B) and Explained Variance $\left(\mathbf{R}^{2}\right)$ for Direct Factors on Intention

\begin{tabular}{|c|c|c|c|c|c|}
\hline Direct factor & Path & Dependent Variable & $\boldsymbol{B}$ & Significance & $R^{2}$ \\
\hline $\begin{array}{l}\text { Perceived Ease of Use } \\
\text { (peou } 2)\end{array}$ & ---------> & Intention (intend2) & .36 & $.002 *$ & .48 \\
\hline $\begin{array}{l}\text { Perceived Usefulness } \\
(p u 2)\end{array}$ & $-->$ & Intention (intend2) & -.07 & .628 & \\
\hline Teacher (teach) & ---------> & Intention (intend2) & .21 & $.038 *$ & \\
\hline Other People (other) & ---------> & Intention (intend2) & .36 & $.001 *$ & \\
\hline Selfeff2 & ---------> & Intention (intend2) & -.059 & .564 & \\
\hline $\begin{array}{l}\text { Perceived Ease of Use } \\
\text { (peou2) }\end{array}$ & $--->$ & Selfeff2 & .32 & $.005^{*}$ & .52 \\
\hline $\begin{array}{l}\text { Perceived Usefulness } \\
(p u 2)\end{array}$ & ---------> & Selfeff2 & .31 & $.019 *$ & \\
\hline Student (stu) & ---------> & Selfeff2 & .03 & .834 & \\
\hline Teacher (teach) & ---------> & Selfeff2 & 1.01 & .315 & \\
\hline Other influncer (other) & ---------> & Selfeff2 & .23 & $.045^{*}$ & \\
\hline
\end{tabular}

The second research question: How do the direct factors of perceived ease of use, (peou2); perceived usefulness (pu2); influencers (stu, teach, and other) relate to teachers' belief on self-efficacy (Selfeff2)? The following Table 3 shows the statistically significant path coefficients $(B)$ from peou 2 to selfeff $2(B=.32 ; \mathrm{p}=.005) ; p u 2$ to selfeff $(B=.31 ; \mathrm{p}=.019)$; and other $(B=.23 ; \mathrm{p}=.045)$ at $\mathrm{p}<.05$. Therefore, the following hypotheses formulated to answer the research questions were accepted:

Hypothesis H5 : There is positive relationship between teachers' belief about perceived ease of use and self-efficacy. Hypothesis H6 : There is positive relationship between teachers' beliefs about perceived usefulness and self-efficacy. Hypothesis H9 : There is positive relationship between teachers' beliefs about others as influencers and self-efficacy Hypotheses H7 (There is positive relationship between teachers' beliefs about teachers (as influencers) self-efficacy. H8 (There is positive relationship between teachers' beliefs about students (as influencer) and self-efficacy are rejected as the path coefficient from teach (teacher as influencer) to self-efficacy, selfeff $2(B=1.01 ; \mathrm{p}=.315)$ and from stu (students as influencers) to selfeff $2(B=.03, \mathrm{p}=.834)$ are not significant at $\mathrm{p}<.05$.

Based on the above findings and discussions, the following conclusions can be made to answer the first two research questions. Firstly, teachers' beliefs about their perception of ease of use of technology, and their beliefs about teachers and others as influencers (people who have significant influence for them to use technology) have direct influence on their intention to use technology in teaching and learning. And secondly, teachers' beliefs about their perception of ease and use of technology, and perception of usefulness; and others as influencers have direct effect on their beliefs about self-efficacy to use technology in teaching and learning.

Finally, the third research question asks: How does the direct factors explain teachers' intention to use technology in teaching and learning? The following Hypothesis H10 was formulated to answer the research question.

Hypothesis 10 (The direct factors (perceived ease of use, perceived usefulness, teachers, students and others as influencers); and self-efficacy provides a significant model fit in explaining teacher intentions to use of technology in teaching and learning. Hypothesis 10 was tested by assessing the performance of the SEM model of direct factors, by examining the significance of each of path coefficient $(B)$; the model fit indices and squared multiple correlations $\left(\mathrm{R}^{2}\right)$ of the two dependent variables, self-efficacy and intention. Two modified TAM models (Figure 2 and Figure 3 ) were generated using AMOS software, and the fit criteria (see Table 4) were compared. 


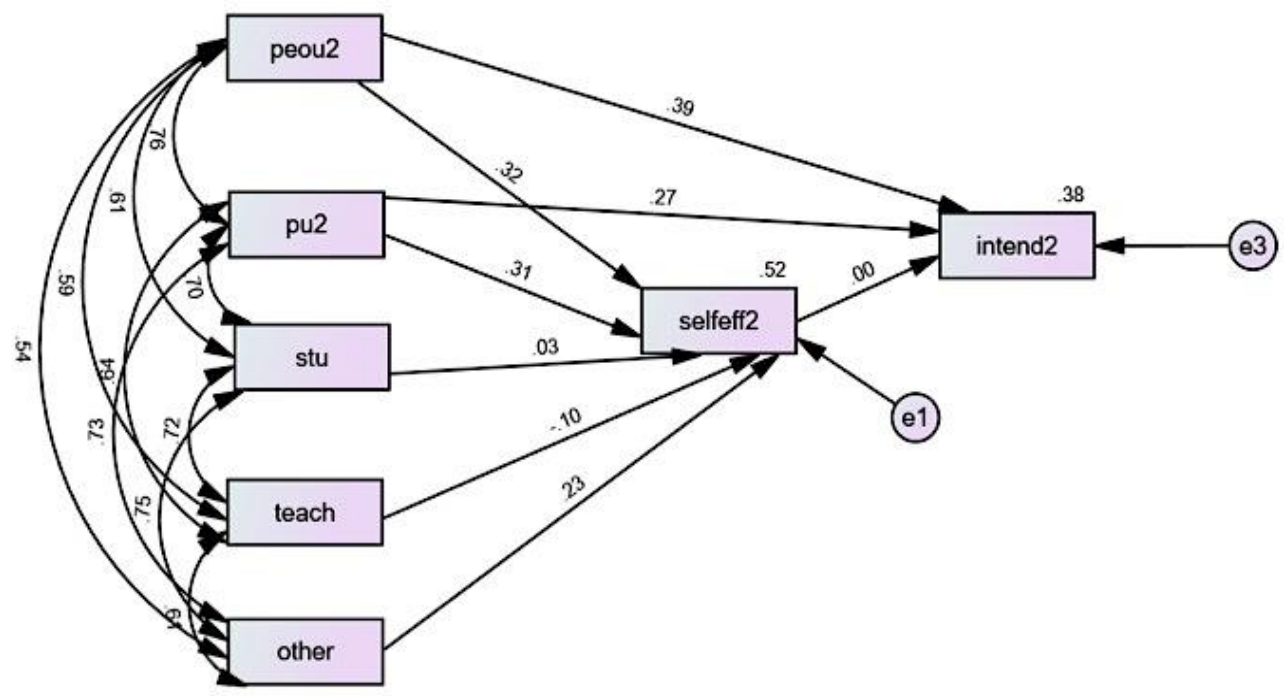

Fig. 3 - Modified TAM Model 1 (before adjustment)

The results of the model fit indices and presented in Table 4 are used to assess the modified TAM model of direct factors in explaining teacher intention to use of technology. From Figure 2, based on the squared multiple correlations $\left(\mathrm{R}^{2}\right)$, it can be seen that the modified TAM2 model explains $48 \%$ of variance in teachers' intention to use technology, and $52 \%$ in teachers' self-efficacy.

Table 4 shows that the fit statistics for the modified Model TAM 1 of direct factors shows most of the fit indices (Normed chi-square, AGFI, NFI, TLI, RMR, and RMSEA) do not conform to the fit criteria. However, after adjustment by making the variables, teach and other; directly link to intend2, the fit criteria improve (see Figure 2). The modified TAM Model 2 of direct factors provides a good fit with all the fit indices conforming to the recommended threshold values for the fit criteria. Therefore, it can be concluded that modified TAM Model 2 of direct factors provides a good fit.

Table 4 - Results of the SEM Model 1 and 2 of direct factors: fit and squared multiple correlations

\begin{tabular}{lccc}
\hline \multicolumn{1}{c}{ Fit measure } & $\begin{array}{c}\text { Before Adjustment } \\
\text { (modified TAM Model 1) }\end{array}$ & $\begin{array}{c}\text { After Adjustment } \\
\text { (modified TAM Model 2) }\end{array}$ & Recommended \\
\hline$\chi^{2}$ & 19.571 & .754 & $\mathrm{p}>.05$ \\
$\begin{array}{l}\text { Degrees of } \\
\text { freedom }\end{array}$ & $\mathrm{p}=.000$ & 1 & \\
Normed $\chi^{2}$ & 3 & & \\
GFI & 6.524 & .754 & Between 1.0 and \\
AGFI & .953 & .998 & 3.0 \\
NFI & .624 & .942 & Over .90 \\
TLI & .560 & .998 & Over .90 \\
RMR & .758 & 1.0 & Over .90 \\
RMSEA & .183 & .028 & Over .90 \\
& .232 & .000 & Lower than .10 \\
$\mathbf{R}^{2}$ & & Self-efficacy & Intention \\
& Explained variance in & $52 \%$ & $48 \%$ \\
\hline
\end{tabular}

In summary, the results show that the direct factors of teachers' beliefs of perceived ease of use, and teachers' beliefs of teachers and other people as influencers (as shown in Table 3) explain significantly TVET teachers' intention to use technology (as shown in Table 3). From Table 4, it was shown TAM model 2 (see Figure 2) is a good fit model to show that the direct factors of teacher' beliefs of perceived ease of use, perceived usefulness, and other people as influencers relate significantly to teachers' self-efficacy. 


\section{Conclusions and Recommendations}

This study posits that TVET teachers' intentions to incorporate technology in their instructions can be influenced by building up their self-efficacy beliefs (their beliefs about their ability and capability to use technology), and to influence their beliefs of the usefulness and ease of use of technology. Underpinned by Technology Acceptance Model as the theoretical framework of the research, a professional development program on technology-enriched instruction was mounted. The study leveraged on the assumptions that the technology-enriched instruction professional development programme would engage TVET teachers to plan and design learning activities using a plethora of technology; and hence would improve their self-efficacy beliefs, and ultimately influences their intention to use technology in teaching and learning.

In conclusion, the current study recommends that there is a need to provide extended support for teachers to work together and design 21 st century teaching and learning that intentionally integrate the use of technology. Extended support in this context refers to the development of teachers' expertise in technology use, and designing and planning lessons that integrate technology for 21 st century skills development. Teachers need to get together and discuss 'what works and 'what needs to be improved in their lessons through teacher collaboration. In doing so, teachers can then design lessons that promote the development of 21 st century skills through effective use of technology. Development of teachers' efficacy through influences such as other people (e.g. parents and community) is also needed for teachers to be motivated to make changes in teaching and learning. These changes can come in various forms, such as using technology to increase student's engagement, improve students' academic performance through various technological platforms. In addition, teachers also need professional guidance from experts in the use of technologies in teaching and learning. Such guidance may have a positive impact on teachers' self-efficacy beliefs towards the use of technology in teaching and learning. The results of this study provide a shred of strong empirical evidence for how professional development of the TVET teachers can be introduced and implemented to provide support requirements for technology integration in their 21 st century teaching and learning; reinforcement and encouragement from colleagues and administrative leaders; and empowerment for teachers to develop their own 21 st century teaching and learning.

\section{Acknowledgement}

We would like to extend our sincere gratitude to the TVET teachers who participated in the technology-enriched instruction professional development workshops, and those who also agreed to respond to the questionnaire.

\section{Reference}

Albion, P. R., Tondeur, J., Forkosh-Baruch, A., \& Peeraer, J. (2015). Teachers' professional development for ICT integration: Towards a reciprocal relationship between research and practice. Education and Information Technologies, 20(4), 655-673. https://doi.org/10.1007/s10639-015-9401-9

Boschman, F., McKenney, S., \& Voogt, J. (2014). Understanding decision making in teachers' curriculum design approaches. Educational Technology Research and Development, 62(4), 393-416. https://doi.org/10.1007/s11423-0149341-x

Chien, S. P., Wu, H. K., \& Hsu, Y. S. (2014). An investigation of teachers' beliefs and their use of technology-based assessments. Computers in Human Behavior, 31(1), 198-210. https://doi.org/10.1016/j.chb.2013.10.037

Cox, M. J. (2010). The changing nature of researching information technology in education. In A. McDougall, J. Murnane, A. Jones, \& N. Reynolds (Eds.), Researching IT in Education: Theory, Practice and Future Directions (1124). New York, NY: Routledge

Davis, F. D. (1989). Perceived usefulness, perceived ease of use, and user acceptance of information technology. MIS Quarterly, 13(3), 319-340

Deng, F., Chai, C. S., Tsai, C. C., \& Lee, M. H. (2014). The relationships among chinese practicing teachers' epistemic beliefs, pedagogical beliefs and their beliefs about the use of ICT. Educational Technology and Society, 17(2), $245-256$.

Duran, E., Yaussy, D., \& Yaussy, L. (2011). Race to the future: Integrating 21st century skills into science instruction. Science Activities: Classroom Projects and Curriculum Ideas, 48(3), 98-106. https://doi.org/10.1080/00368121.2010.535222

Ebil, S. H., Salleh, S. M., \& Shahrill, M. (2020). The use of E-portfolio for self-reflection to promote learning: A case of TVET students. Education and Information Technologies, 1-18. https://doi.org/10.1007/s10639-020-10248-7

Ehlers, M., Schuwer, R., \& Janssen, B. (2018). Open Educational Resources for skills development. Retrieved from https://unevoc.unesco.org/up/OER-in-TVET.pdf

Erstad, O., Eickelmann, B., \& Eichborn, K. (2015). Preparing teachers for schooling in the digital age: A meta-perspective on existing strategies and future challenges. Education and Information Technologies, 20, 641-654 
Hsu, P. S. (2016). Examining current beliefs, practices and barriers about technology integration: A case study. TechTrends, 60(1), 30-40. https://doi.org/10.1007/s11528-015-0014-3

Inan, F. A., Lowther, D. L., Ross, S. M., \& Strahl, D. (2010). Pattern of classroom activities during students' use of computers: Relations between instructional strategies and computer applications. Teaching and Teacher Education, 26(3), 540-546. https://doi.org/10.1016/j.tate.2009.06.017

Kale, U., \& Goh, D. (2014). Teaching style, ICT experience and teachers' attitudes toward teaching with Web 2.0. Education and Information Technologies, 19(1), 41-60. https://doi.org/10.1007/s10639-012-9210-3

Kay, K., \& Greenhill, V. (2011). Twenty-first century students need 21st century skills. In D. Wan, \& G. Gut (Eds.), Bringing Schools into the 21st century (pp. 41-65). Dordrecht: Springer

Kim, C., Kim, M. K., Lee, C., Spector, J. M., \& DeMeester, K. (2013). Teacher beliefs and technology integration. Teaching and Teacher Education, 29(1), 76-85. https://doi.org/10.1016/j.tate.2012.08.005

Lai, J. W. M., \& Bower, M. (2019). How is the use of technology in education evaluated? A systematic review. Computers \& Education, 133, 27-42. https://doi.org/10.1016/j.compedu.2019.01.010

Lambert, J., \& Gong, Y. (2010). 21st century paradigms for pre-service teacher technology preparation. Computers in the Schools, 27(1), 54-70. https://doi.org/10.1080/07380560903536272

Livingstone, S. (2012). Critical reflections on the benefits of ICT in education. Oxford Review of Education, 38(1), 924. https://doi.org/10.1080/03054985.2011.577938

Ramadan, A., Chen, X., \& Hudson, L. L. (2018). Teachers' skills and ICT integration in technical and vocational education and training TVET: A case of Khartoum State-Sudan. World Journal of Education, 8(3), 31-43. https://doi.org/10.5430/wje.v8n3p31

Salleh, S. (2016). Examining the influence of teachers' beliefs towards technology integration in classroom. International Journal of Information and Learning Technology, 33(1), 17-35. https://doi.org/10.1108/IJILT-10-2015-0032

Salleh, S. M., \& Laxman, K. (2014). Headmasters and information and communication technology: Approaches in making the connection. Research and Practice in Technology Enhanced Learning, 9(2), 349-362

Slykhuis, D. A., \& Lee, J. (2016). Using two frameworks to promote e-leadership and teacher development. In R. Huang, Kinshuk, \& J. Price (Eds.), ICT in Education in Global Context: Lecture Notes in Educational Technology. Springer, Berlin, Heidelberg. https://doi.org/10.1007/978-3-662-47956-8_12

Tondeur, J., Van Braak, J., Ertmer, P. A., \& Ottenbreit-Leftwich, A. (2017). Understanding the relationship between teachers' pedagogical beliefs and technology use in education: a systematic review of qualitative evidence. Educational Technology Research and Development, 65(3), 555-575

Vongkulluksn, V. W., Xie, K., \& Bowman, M. A. (2018). The role of value on teachers' internalization of external barriers and externalization of personal beliefs for classroom technology integration. Computers and Education, 118, 70 81. https://doi.org/10.1016/j.compedu.2017.11.009

Voogt, J., Fisser, P., Pareja Roblin, N., Tondeur, J., \& van Braak, J. (2013). Technological pedagogical content knowledge - A review of the literature. Journal of Computer Assisted Learning, 29(2), 109-121. https://doi.org/10.1111/j.1365-2729.2012.00487.x

Voogt, J., \& McKenney, S. (2017). TPACK in teacher education: Are we preparing teachers to use technology for early literacy? Technology, Pedagogy and Education, 26(1), 69-83. https://doi.org/10.1080/1475939X.2016.1174730

Wood, K., Jaidin, J. H., Jawawi, R., Perera, J. S. H. Q., Salleh, S. M., Shahrill, M., \& Sithamparam, S. (2017). How and what teachers learn from collaborative professional development. International Journal for Lesson and Learning Studies, 6(2), 151-168

Yasak, Z., \& Alias, M. (2015). ICT integrations in TVET: Is it up to expectations? Procedia - Social and Behavioral Sciences, 204(November 2014), 88-97. https://doi.org/10.1016/j.sbspro.2015.08.120 